\title{
Sero-prevalence of Ovine Brucellosis in Jaipur, Rajasthan, India
}

\author{
Om Prakash Meena ${ }^{1 *}$, Nirmal Kumar Jeph ${ }^{2}$, Mamta Meena ${ }^{3}$, D.S. Meena ${ }^{2}$ and Rashmi Singh ${ }^{2}$ \\ ${ }^{1}$ Department of Veterinary Medicine, A.C.V.M. Jaipur, Rajasthan, INDIA \\ ${ }^{2}$ Department of Veterinary Medicine, P.G.I.V.E.R Jaipur, Rajasthan, INDIA \\ ${ }^{3}$ Department of Veterinary Pharmacology and Toxicology, A.C.V.M. Jaipur, Rajasthan, INDIA \\ "Corresponding author: OP Meena; E-mail: dropmeena399@gmail.com
}

Received: 14 July, 2021

Revised: 28 Aug., 2021

Accepted: 03 Sept., 2021

\begin{abstract}
Brucellosis is a reproductive disease of livestock that is of immense economic importance. It predominates in most developing countries like India. The disease mainly causes infertility, delayed heat, disrupted lactation, and abortion, decrease of wool, meat and milk production which is of zoonotic value to humans. Brucellosis is transmitted to human through direct or indirect contact with infected animal and material or through the ingestion of animal byproducts. Sheep are natural reservoir of brucella and mainly infected by Brucella melitensis. Sheep mainly reared for wool, meat and occasionally for milk. Sheep skin and manure are also significant earning sources for farmers. The present study was carried out to know the age and sex wise sero-prevalence of brucellosis in sheep in and around Jaipur. A total number of 360 sera samples were collected from different locations of Jaipur from sheep and were tested by serological methods viz. Rose Bengal Plate Test (RBPT), Standard Tube Agglutination Test (STAT) and Indirect Enzyme Linked Immuno-Sorbent Assay (i-ELISA). The prevalence was 3.33\%, 6.67\% and $10.00 \%$ by RBPT, STAT, and i-ELISA respectively in more than 3 years of age group of sheep. In less than 3 years age group the prevalence were $1.33 \%, 6.33 \%$ and $6.67 \%$ using RBPT, STAT \& i-ELISA respectively. The study revealed $6.25 \%$ prevalence both by RBPT and STAT \& $9.37 \%$ by i.ELISA in male population. In female population the study revealed $0.67 \%, 6.41 \%$ and $6.75 \%$ by RBPT, STAT and i-ELISA respectively.

\section{HIGHLIGHTS}

(0 Study focused on Age and Sex wise sero-prevalence of brucellosis in sheep.

(0 Sheep is one of the important livestock of Rajasthan.

(0 Brucellosis possesses a serious hazard to human health and it is also a disease in domestic animals with important economic consequences.
\end{abstract}

Keywords: Age wise, brucellosis, sero-prevalence, sex wise, sheep

Sheep is an important and profitable livestock in India. The total livestock population of India is 536.76 million in which sheep population is 74.26 million. Sheep is an important species which contributes $13.83 \%$ of livestock population in India. India ranks second in sheep population in world after China. Rajasthan has fourth place in sheep population in India. Total population of sheep in Rajasthan is 7.9 million. Out of which 0.25 million sheep population is found in Jaipur district (DAH, GoI, 2019).

Sheep products (mutton, wool, milk etc.) are an important component of rural economy particularly in the arid, semi-arid and mountainous areas of the country. Sheep contributes significantly to the Indian economy by sustaining livelihood and supplementing the income of small farmers. Sheep is a profitable animal for small farmers. In India sheep are used for dual purpose, viz., wool and mutton. Sheep and goats are main meat

How to cite this article: Meena, O.P., Jeph, N.K., Meena, M., Meena, D.S. and Singh, R. (2021). Sero-prevalence of Ovine Brucellosis in Jaipur Rajasthan, India. J. Anim. Res., 11(05): 837-841.

Source of Support: None; Conflict of Interest: None क्) 
producers in India. The total meat production in country was about 7.0 million tons during 2015-16 of which sheep meat contributed $7 \%$. The major income (70\%) in sheep farming comes from sale of live animals for mutton purpose (Madhu Mohini et al., 2018).

Brucellosis is an important disease of sheep causing infertility, repeat breeding, retention of placenta and abortion. In sheep brucellosis poses a barrier to trade of animals and animal products between countries and causes considerable economic losses. Middle East countries like Saudi Arabia, by far the largest market for live sheep in the world requires $100 \%$ testing for brucellosis (Girmay et al., 2013).

In sheep brucellosis caused by Brucella melitensis and Brucella ovis. Brucella melitensis is one of the most virulent species and responsible for important economic losses in sheep farming (Montasser et al., 2011). Sheep brucellosis can be divided into ram epididymitis and classical brucellosis. Ram epididymitis is caused by Brucella ovis while classical brucellosis is caused by Brucella melitensis (Lone et al., 2013).

The means of transmission of brucellosis are through ingestion and direct or indirect contact with excretion of the organisms in uterine discharge and milk of infected female. In small ruminants, most common symptoms are usually abortion during the last term pregnancy including weak offspring, retained placenta and metritis which may result in temporary infertility. Other symptoms epididymitis and orchitis occur in rams. Some animals with polyarthritis have been observed in endemic flocks (Padher et al., 2017).

Brucellosis is also known as Bang's disease, Malta fever, Contagious abortion, Mediterranean fever, Enzootic abortion, Epizootic abortion and Undulant fever (Abubakar et al., 2012; Din et al., 2013). After rabies, brucellosis is an important zoonotic disease which causes significant reproductive losses in sexually mature animals and affects economy of country (Lopes et al., 2010; Abubakar et al., 2012).

In India, first case of brucellosis was found in 1887 and since then the cases are being observed in almost all the states of the country. The overall prevalence of disease was found in sheep in India was $6.23 \%$ (Saminathan et al., 2016). Many factors such as absence of a control policy, failure to vaccinate young female animals, absence of treatment regimen and usual practice of selling positive reactor animals to other farmers are responsible for the spread of this disease among livestock in India (Singh et al., 2015).

For diagnosis of brucellosis in animals a large number of serological tests are available of which Rose Bengal Plate Test (RBPT), Standard Tube Agglutination Test (STAT), Enzyme Linked Immuno-Sorbent Assay ELISA (d-ELISA, p-ELISA, i-ELISA), Polymerase Chain Reaction (PCR), Agar Gel Immuno Diffusion (AGID) and Complement Fixation Test (CFT) have been used extensively to diagnose brucellosis in animals (Reddy et. al., 2014, Saxena et al., 2018). Comparative studies have shown that i-ELISA has better sensitivity than either the AGID test or the CFT (OIE, 2012).

Thus, due to paucity of epidemiological data including age and sex wise sero-prevalence of sheep brucellosis in and around Jaipur, this study has been proposed with the objective to study the prevalence of brucellosis in sheep in and around Jaipur.

\section{MATERIALS AND METHODS}

Samples were collected to study the sero-prevalence of brucellosis in sheep from un-organized sector in Jaipur and around in Jaipur. Three hundred and sixty blood samples were collected randomly from different places which comprising samples from apparently healthy animals; particularly in terms of age and sex. All samples were subjected to RBPT, STAT and i- ELISA tests for diagnosis of brucellosis in sheep.

After proper restraining of the sheep, $5 \mathrm{ml}$ blood was withdrawn aseptically by jugular vein puncture using disposable syringe with 20 gauge needle from each animal. After collection of blood tubes were kept for 2 to 3 hours in slanting position at room temperature and centrifuged at $3000 \mathrm{rpm}$ for 10 minutes. Serum was immediately transferred to sterile screw capped cryovials and stored at $-20^{\circ} \mathrm{C}$ till further analysis. Collected serum samples were subjected to Rose Bengal Plate Test (RBPT), Standard Tube Agglutination Test (STAT) and i-ELISA.

Rose Bengal antigen and B. abortus plain antigen were used for RBPT and STAT respectively. These antigens were procured from Division of Biological product, Indian 
Veterinary Research Institute, Izatnagar - 243122, (U.P.). Both antigens were stored at $4^{\circ} \mathrm{C}$ before and after use.

RBPT was carried out by coloured antigen with the method of Alton et al. (1975). $0.3 \mathrm{ml}$ of antigen was mixed with $0.3 \mathrm{ml}$ of serum and observed for clump formation.

STAT was performed in clean glass tubes according to the method described by Alton et al. (1975). Brucella abortus plain antigen (Division of Biological Products, Indian Veterinary Research Institute, Izatnagar- 243122 U.P.) was employed for the test. The highest serum dilution showing $50 \%$ agglutination was taken as the end point for the titer of serum. A titer of 1:40 or above was considered positive.

i-ELISA was performed by using ID Screen ${ }^{\circledR}$ Brucellosis Serum Indirect Multi-Species kit manufactured by ID Vet Innovative Diagnostics. The test was performed as per protocol outline in the user manual supplied with kit. The diagnostic kit is designed to detect antibodies directed against Brucella abortus (bovine), Brucella melitensis (ovine and caprine) and Brucella suis (pigs).

\section{RESULTS AND DISCUSSION}

Brucellosis is an important but neglected disease in India. Brucellosis is still one of the most important zoonotic diseases, leading to huge economic losses to dairy farmers and is a major health hazard in India. These losses results through abortion, infertility, stillbirth in animals and reduction in milk yield. In human beings it causes undulant fever and they get infection from animals through direct or indirect contact with aborted foetus, placenta, uterine discharges and consumption of contaminated milk and milk products (Gill et al., 2000).

A total of 360 serum samples were collected and tested for evaluation of sero-prevalence of brucellosis in sheep in and around Jaipur. All the 360 samples were subjected for brucellosis infection by RBPT, STAT and i-ELISA, in animals in the age group of less than 3 years and more than three years of sheep. Further the samples were analysed for the sex wise distribution by using the above methods. The results are as stated below:

\section{Age wise prevalence}

Animals were divided in two age groups i.e. less than 3 years and more than 3 years. Highest prevalence was observed in more than 3 years age group as $3.33 \%, 6.67 \%$ and $10.0 \%$ by RBPT, STAT and i-ELISA, respectively; (Table 1; Fig. 1) followed by less than 3 years age group as $1.33 \%, 6.33 \%$ and $6.67 \%$ by RBPT, STAT and i-ELISA respectively. Findings revealed that adult age group of sheep are more susceptible than younger age group for brucellosis.

Table 1: Age wise sero-prevalence of brucellosis in sheep

\begin{tabular}{lllll}
\hline $\begin{array}{l}\text { Age-group } \\
\text { years }\end{array}$ & $\begin{array}{l}\text { No. of } \\
\text { animals }\end{array}$ & $\begin{array}{l}\text { RBPT } \\
+\mathbf{v e}\end{array}$ & $\begin{array}{l}\text { STAT } \\
+\mathbf{v e}\end{array}$ & $\begin{array}{l}\text { i- ELISA } \\
+\mathbf{v e}\end{array}$ \\
\hline $\begin{array}{l}\text { Less than } 3 \\
\text { years }\end{array}$ & 300 & 4 & 19 & 20 \\
\hline $\begin{array}{l}\text { More than 3 } \\
\text { years }\end{array}$ & 60 & 2 & 4 & 6 \\
\hline
\end{tabular}

The age wise sero-prevalence in sheep was found higher in adult (in more than 3 year) age group. Similar to this value Shafy et al. (2016) reported higher prevalence value in adult sheep (57\%) than young sheep (8.1\%).

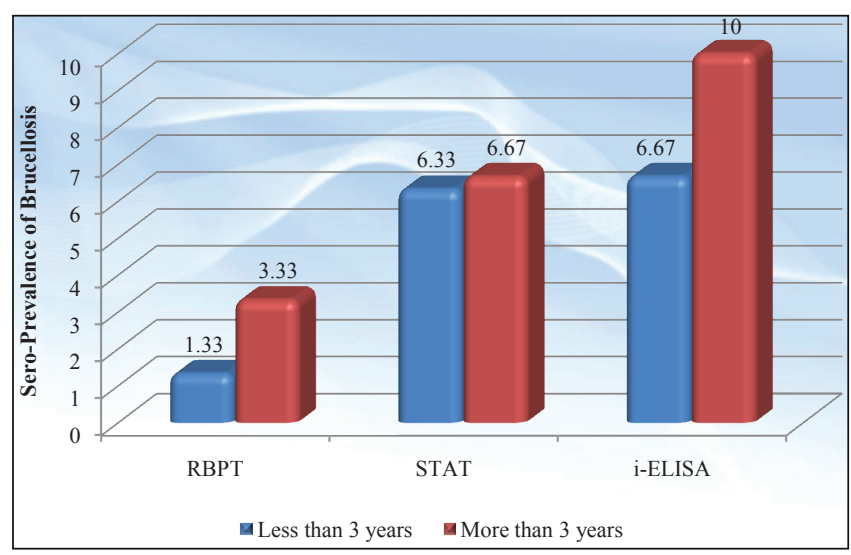

Fig. 1: Age wise sero-prevalence of brucellosis in Sheep

\section{Sex wise prevalence}

The prevalence value were found higher in males as $6.25 \%, 6.25 \%$ and $9.37 \%$ by RBPT, STAT and i-ELISA respectively (Table 2; Fig. 2). All serological tests showed higher prevalence in males as compare to female, but it seems that STAT recorded relatively higher prevalence of brucellosis in female compared to other two serological tests. The prevalence reported $6.41 \%$ in female which was found higher than males as $6.25 \%$ by STAT. 
Table 2: Sex wise sero-prevalence of brucellosis in sheep

\begin{tabular}{llll}
\hline $\begin{array}{l}\text { Sex (No. of } \\
\text { samples) }\end{array}$ & $\begin{array}{l}\text { RBPT +ve } \\
(\%)\end{array}$ & $\begin{array}{l}\text { STAT +ve } \\
(\%)\end{array}$ & $\begin{array}{l}\text { i - ELISA +ve } \\
(\%)\end{array}$ \\
\hline Male (64) & 4 & 4 & 6 \\
& $(6.25)$ & $(6.25)$ & $(9.37)$ \\
\hline $\begin{array}{l}\text { Female } \\
(296)\end{array}$ & 2 & 19 & 20 \\
\hline
\end{tabular}

Suryawanshi et al. (2014) also reported higher seroprevalence in male sheep $25 \%$ than female sheep $17.16 \%$. While Shafy et al. (2016) reported that the prevalence was found higher in female sheep $39.2 \%$ than male sheep 18\%.

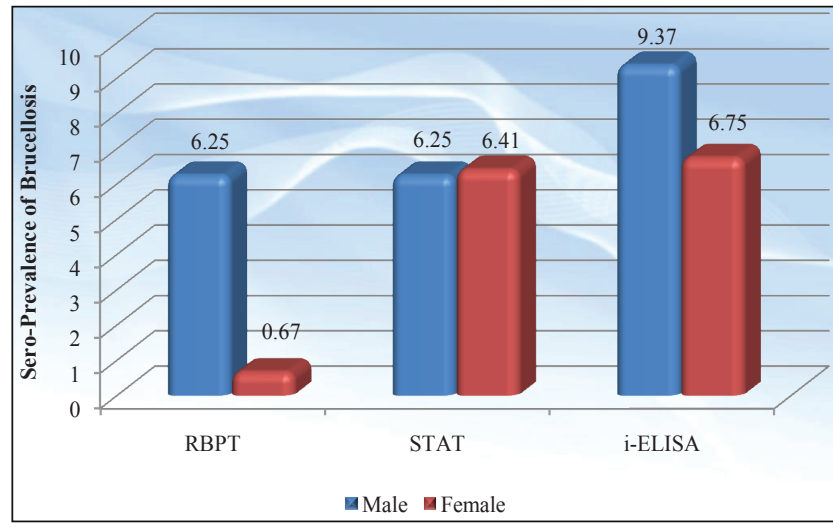

Fig. 2: Sex wise sero-prevalence of brucellosis in sheep

\section{STATISTICAL ANALYSIS}

\section{RBPT}

Sero-prevalence of brucellosis in sheep was found as $1.67 \%$ by RBPT. Analysis of variation was performed to know the effect of age and sex on prevalence of brucellosis. Effect of age was observed as non-significant on brucellosis diagnosed by RBPT. Significant effect was found for sex on brucellosis for RBPT test. Higher prevalence was observed in male as $(0.051 \pm 0.017)$ than female $(0.016 \pm 0.010)$ (Table 3\&4).

\section{STAT}

The statistical differences estimated using ANOVA for sero-prevalence and variables for the individual risk factor were observed as non-significant on brucellosis diagnosed by STAT. The age group less than 3 years had less STAT sero-positives then more than 3 years age group. The seroprevalence of brucellosis in sheep was observed as $6.38 \%$ by STAT. Prevalence of brucellosis was estimated as $6.9 \%$ in male and $7.4 \%$ in female (Table $3 \& 4$ ).

\section{i-ELISA}

The statistical differences estimated using ANOVA for sero-prevalence and variables for the individual risk factor were observed as non-significant on brucellosis diagnosed by i-ELISA. The age group less than 3 years had $6.67 \%$ prevalence by i-ELISA . The age group more than 3 years old had the prevalence of $10 \%$ by I. ELISA. The seroprevalence of brucellosis in sheep was observed as 7.22\% by i-ELISA. Prevalence of brucellosis was estimated as $9.37 \%$ in male and $6.35 \%$ in female (Table $3 \& 4$ ).

Table 3: Estimates $(\mathrm{LSM} \pm \mathrm{SE})$ of brucellosis prevalence RBPT, STAT, i-ELISA

\begin{tabular}{llllll}
\hline & & \multicolumn{2}{c}{ Least Square Mean \pm Standard Error } \\
\cline { 3 - 6 } Particulars Prevalence & \multicolumn{2}{c}{ Age } & \multicolumn{2}{c}{ Sex } \\
\cline { 3 - 6 } & & $\begin{array}{l}\text { Less than } \\
\text { 3 years }\end{array}$ & $\begin{array}{l}\text { More } \\
\text { than } \\
\text { 3 years }\end{array}$ & Male & Female \\
& & $0.025 \pm$ & $0.042 \pm$ & $0.051 \pm$ & $0.016 \pm$ \\
RBPT & $1.67 \%$ & 0.010 & 0.017 & $0.017 *$ & $0.010^{*}$ \\
& & $0.058 \pm$ & $0.085 \pm$ & $0.069 \pm$ & $0.074 \pm$ \\
STAT & $6.38 \%$ & 0.018 & 0.033 & 0.032 & 0.019 \\
& & $0.080 \pm$ & $0.113 \pm$ & $0.117 \pm$ & $0.076 \pm$ \\
i-ELISA & $7.22 \%$ & 0.019 & 0.035 & 0.034 & 0.020 \\
\hline
\end{tabular}

$* \mathrm{P} \leq 0.05$.

Table 4: ANOVA for brucellosis by RBPT, STAT, i-ELISA

\begin{tabular}{lllll}
\hline $\begin{array}{l}\text { Source of } \\
\text { Variance }\end{array}$ & $\begin{array}{l}\text { Degree of } \\
\text { Freedom }\end{array}$ & $\begin{array}{l}\text { Mean } \\
\text { Squares/ } \\
\text { RBPT }\end{array}$ & $\begin{array}{l}\text { Mean } \\
\text { Squares// } \\
\text { STAT }\end{array}$ & $\begin{array}{l}\text { Mean } \\
\text { Squares/ } \\
\text { i-ELISA }\end{array}$ \\
\hline Age & 1 & 0.014 & 0.035 & 0.050 \\
Sex & 1 & 0.063 & 0.001 & 0.090 \\
Error & 357 & 0.016 & 0.060 & 0.067 \\
\hline
\end{tabular}




\section{CONCLUSION}

A total of 360 serum samples were collected from sheep in and around Jaipur. All the samples were subjected to RBPT, STAT and i-ELISA. In Sheep, the highest prevalence was observed in more than three year age group as $3.33 \%, 6.67 \%$ and $10.00 \%$ by RBPT, STAT and i-ELISA, respectively. Also, the prevalence was found higher in males as $6.25 \%, 6.25 \%$ and $9.37 \%$ by RBPT, STAT and i-ELISA, respectively. Findings of this study suggest that the prevalence of brucellosis is higher and it is an indication for further large scale investigations of population for brucellosis by which actual occurrence of disease in population can be determined and further timely preventive measure can be taken to prevent the disease.

\section{ACKNOWLEDGMENTS}

The authors are thankful to Dr. D. S. Meena, Prof. and Head, Dept. of Veterinary Medicine (Incharge, Veterinary Clinical Complex and PI, RKVY Project- CDSRZ) PGIVER Jaipur for financial support and allowing to work in the laboratory during research work and for their continuous motivation and indispensable suggestions and counselling during the study and research period.

\section{REFERENCES}

Abubakar, M., Mansoor, M. and Arshed, M.J. 2012. Bovine brucellosis: old new concepts with Pakistan perspective. Pak. Vet. J., 32 (2): 147-155.

Alton, G.G., Jones, L.M. and Pietz, D.E. 1975. Laboratory techniques in brucellosis. World Health Organization Monograph Series, 55: 163.

Department of Animal Husbandry, Government of India (2019). $20^{\text {th }}$ Livestock Census Report. http://animalhusbandry.india. gov.in/Animal.

Din, A.M.U., Khan, S.A., Ahmad, I., Rind, R., Hussain, T., Shahid, M. and Ahmed, S. 2013. A study on the seroprevalence of brucellosis in humans and goats populations of district Bhimber, Azad J \& K. J. Anim. Plant Sci., 23: 113-118.

Gill, J., Kaur, S., Joshi, D.V. and Sharma, J.K. 2000. Epidemiological studies on brucellosis in farm animals in Punjab state of India and ITS public health significance. Abstract in: $9^{\text {th }}$ International symposium on veterinary epidemiology and economics.

Girmay, A., Hussien, D. and Afera, B. 2013. Seroprevalence of ovine brucellosis in a sheep export farm, Ethiopia. Glob. Vet., 11(3): 325-328.
Lone, I.M., Baba, M.A., Shah, M.M., Iqbal, A. and Sakina, A. 2013. Seroprevalence of brucellosis in sheep of organized and unorganized sector of Kashmir valley. Vet. World, 6(8): 530-533.

Lopes, L.B., Nicolino, R. and Haddad, J.P.A. 2010. Brucellosis - risk factors and prevalence: a review. Open Vet. Sci. J., 4: 72-84.

MadhuMohini, Malla, B.A. and Mondal, G. 2018. Small ruminant sector in India: present status, feeding systems and greenhouse gas emissions. Ecronicone Vet. Sci., 3(1): 281289.

Montasser, A.M., Affi, M.M., El-Bagoumy, E.M., Abdul-Raouf U.M. and Mohamad, H.A. 2011. Efficacy of serological tests for detection of brucellosis in ruminants at south provinces of Egypt. Glob. Vet., 6(2): 156-161.

O I E, World organization for animal health, 2012. Caprine and Ovine brucellosis, manual of diagnostic tests and vaccines for terrestrial animals (mammals, birds and bees). OIEWHO, 7(2): 968-977.

Padher, R.R., Nayak, J.B., Brahmbhatt, M.N. and Mathakiya, R.A. 2017. Comparative sensitivity \& specificity of various serological tests for detection of brucellosis in small ruminants. Int. J. Curr. Microiol. Appl. Sci., 6(5): 2090-2099.

Reddy, D.A., Kumari, G., Rajagunalan, S., Singh, D.K., Kumar, A. and Kumar, P. 2014. Sero-prevalence of caprine brucellosis in Karnataka. Vet. World, 7 (3): 182-188.

Saminathan, M., Rana, R., Ramakrishnan, M.A., Karthik, K., Malik, Y.S. and Dhama, K. 2016. Prevalence, diagnosis, management and control of important diseases of ruminants with special reference to Indian scenario. J. Exp. Biol. Agric. Sci., 4(3): 338-367.

Saxena, N., Singh, B. B. and Saxena, H.M. 2018. Brucellosis in sheep and goats and its sero-diagnosis and epidemiology. Int J. Curr. Microiol. Appl. Sci., 7(01): 1848-1877.

Shafy, N.M., Ahmed, B.S., Sarker, R.R., Millat, K.S.A., Hasan, M.T., Bhattacharjee, P.K., Chakrabartty, A., Paul, A., Sarker, M.A.S., Truong, T. and Rahman, M.S. 2016. Serological prevalence of ovine and caprine brucellosis in Bangladesh. Bangladesh J. Vet. Med., 14(9): 209-213.

Singh, B.B., Dhand, N.K. and Gill, J.P.S. 2015. Economic losses occurring due to brucellosis in Indian livestock populations. Prev. Vet. Med., 3776: 1-5.

Suryawanshi, S.N., Tembhurne, P.A., Gohain, S. and Ingle, V.C. 2014. Prevalence of brucella antibodies in sheep and goats in Maharashtra. Ind. Res. J. Ext. Edu., 14(4): 75-77. 
